\title{
Kemandirian Anak Usia Dini dengan Penggunaan Media Film Animasi "Nussa dan Rara"
}

\author{
Euis Lisefti Fatimah1, Yuyun Yulianingsih², Syam'iyah ${ }^{3}$ \\ PIAUD, UIN Sunan Gunung Djati Bandung, Indonesia \\ e-mail : euislisefti.elf@gmail.com ${ }^{1}$,yuyunyulianingsih67@gmail.com² \\ ade.syamiyah@gmail.com ${ }^{3}$
}

\begin{abstract}
ABSTRAK. Penelitian ini bertujuan untuk mengetahui hubungan antara aktivitas anak pada penggunaan media film animasi "Nussa dan Rara" dengan kemandirian anak usia dini di RA Mubarokah Firrizqi Ciamis. Penelitian ini menggunakan metode penelitian korelasional dengan pendekatan kuantitatif. Data didapat dengan cara observasi, wawancara, angket dan dokumentasi. Analisis data yang digunakan dalam penelitian ini dengan cara mengumpulkan data yang bersifat kuantitatif dengan skala penilaian yang telah ditentukan, menghitung tingkat hubungan, dan diinterpretasikan melalui kesimpulan. Hasil penelitian ini menunjukkan bahwa adanya hubungan yang positif antara kemandirian anak usia dini dengan aktivitas anak pada penggunaan media film animasi "Nussa dan Rara".
\end{abstract}

Kata Kunci : Anak Usia Dini, Kemandirian, Media Film Animasi

ABSTRACT. This aims to determine the relationship between children's activities on the use of animated movie of "Nussa and Rara" with independence of early childhood in RA Mubarokah Firrizqi Ciamis. This study uses a correlational research method with a quantitative approach. Data obtained by means of observation, interviews, questionnaires, and documentation. Analysis of the data used in this study by collecting quantitative data with a predetermined rating scale, calculating the level of relationship, and interpreting it through conclusions. The results of this study indicate that there is a positive relationship between early childhood independence and children's activities in the use of animated movie media of "Nussa and Rara".

Keyword : Early Childhood, Independence, Animated Movie Media 


\section{PENDAHULUAN}

Masa anak usia dini merupakan masa keemasan atau disebut dengan golden age dimana pada masa ini otak mengalami perkembangan yang cukup pesat. Menurut Mursid usia dini merupakan kesempatan emas bagi anak untuk belajar, sehingga disebut usia emas (golden age). Pada usia ini, anak memiliki kemampuan untuk belajar yang luar biasa[1]. Menurut Sumantri anak usia dini berada pada masa lima tahun pertama yang disebut The Golden Age. Masa ini merupakan masa emas perkembangan anak[2]. Oleh karena itu, pemberian stimulus dan perhatian terhadap perkembangan dapat membantu memaksimalkan proses pertumbuhan dan perkembangan anak. Menurut Permendikbud nomor 37 tahun 2014 dinyatakan bahwa salah satu tujuan pendidikan anak usia dini merupakan untuk merangsang dan memaksimalkan aspek-aspek perkembangan yang harus dikembangkan oleh pendidik[3]. Aspek-aspek perkembangan tersebut diantaranya adalah aspek agama dan moral, fisik motorik, kognitif, sosial emosional, bahasa, dan seni. Anak usia dini merupakan dasar awal yang menentukan kehidupan suatu bangsa di masa yang akan datang, sehingga diperlukan persiapan generasi penerus bangsa dengan mempersiapkan anak untuk tumbuh dan berkembang secara optimal baik dalam perkembangan moral, fisik/motorik, kognitif, bahasa, maupun sosial emosional. Setiap anak berhak untuk mendapatkan penghidupan dan perlindungan yang layak, serta dapat tumbuh dan berkembang secara optimal[4]. Suyadi juga berpendapat bahwa pendidikan anak usia dini sebagai salah satu bentuk penyelenggaraan pendidik yang menitipberatkan pada peletakan dasar ke arah pertumbuhan dan perkembangan fisik (koordinasi motorik halus dan kasar), kecerdasan (daya pikir, daya cipta, kecerdasan emosi, kecerdasan spiritual), sosial emosional (sikap dan perilaku serta agama), bahasa dan komunikasi, sesuai dengan keunikan dan tahap- tahap perkembangan yang dilalui oleh anak usia dini[5].

Salah satu aspek yang dikembangkan adalah aspek perkembangan sosial emosional. Kehidupan sosial anak berkembang dengan cara yang relatif dapat di prediksi. Perkembangan sosial selama 2 tahun pertama meliputi perkembangan tandatanda sosial diantara teman sebaya, gaya sosial pada masa toddler berhubungan dengan sejarah kelekatan[6]. Standar tingkat pencapaian perkembangan anak tersebut tertuang dalam kompetensi dasar dan indikator diantaranya adalah dapat berinteraksi dengan teman sebaya dan orang dewasa, dapat menunjukkan rasa percaya diri, dapat menunjukkan sikap kemandirian, dapat menunjukkan emosi yang wajar, terbiasa menunjukkan sikap kedisiplinan dan mentaati aturan, dapat bertanggung jawab, dan terbiasa menjaga lingkungan. Menurut Kania ada 4 parameter yang dipakai dalam menilai perkembangan anak yaitu: gerakan motorik kasar (pergerakan dan sikap tubuh), gerakan motorik halus (menggambar, memegang suatu benda dll), bahasa (kemampuan merespon suara, mengikuti perintah, berbicara spontan), dan kepribadian/tingkah laku (bersosialisasi dan berinteraksi dengan lingkungannya)[7].

Menurut Steinberg dalam Susanto, kemandirian adalah suatu kemampuan untuk mengatur diri sendiri (self governing person). Steinberg juga mengistilahkan kemandirian menggunakan kata lain yaitu independence yaitu kebebasan untuk memperlakukan dirinya sendiri dalam menjalankan aktivitasnya sendiri terlepas dari 
pengawasan orang lain maupun orang tua[8]. Kemandirian merupakan salah satu ciri dalam perkembangan psikologis anak usia pra sekolah yang ditandai dengan munculnya keinginan anak untuk mengurus dirinya sendiri atau mandiri. Kemandirian merupakan salah satu kebiasaan positif yang harus dimiliki oleh setiap orang. Kemandirian juga merupakan salah satu komponen pembentukkan social life skill yaitu kemampuan dasar yang harus dimiliki anak agar mampu menyesuaikan diri dengan lingkungan sosialnya[9].

Kemandirian memiliki dampak yang positif terhadap perkembangan setiap individu, maka anak harus diajarkan tentang kemandirian sedini sesuai dengan kemampuannya. Latihan kemandirian anak harus disesuaikan dengan tahapan usia anak. Contohnya usia 3 tahun anak diajarkan untuk membereskan alat mainan sendiri yang sudah digunakan, makan tanpa disuapi orang tua. Kemandirian anak oleh ibu yang bekerja digambarkan dalam penelitian Geofanny yang menunjukkan hasil bahwa tingkat kemandirian anak yang diasuh oleh ibu yang bekerja lebih tinggi dibandingkan dengan anak yang diasuh oleh ibu yang tidak bekerja[10].

Pada saat melaksanakan pra-observasi yang dilakukan di RA Mubarokah Firrizqi Ciamis menunjukkan bahwa kemandirian anak usia dini masih berada dalam kategori rendah. Pada saat kegiatan, terlihat anak yang masih memerlukan bantuan orang lain dalam melakukan aktivitasnya sehari-hari, kurangnya keberanian tampil di depan orang lain, kurang percaya diri, dan saat kegiatan berwudhu masih harus dibantu. Dan hasil wawancara pun dikatakan oleh pendidik bahwa masih terdapat anak yang kemandiriannya belum berkembang, hal itu dikarenakan kurangnya kesadaran orang tua anak untuk menstimulus setiap perkembangan anak. Oleh karena itu pendidik dapat memilih berbagai metode dan media yang berkaitan dengan kemandirian. Salah satu media pembelajaran yaitu film animasi, dalam penelitian ini yang digunakan film animasi "Nussa dan Rara". Film dapat digunakan sebagai media untuk menunjang berlangsungnya pembelajaran. Manfaat film animasi dalam proses belajar menurut Ronald H. Anderson salah satunya adalah untuk mempengaruhi sikap dan emosi, yakni dengan menggunakan berbagai cara dan efek. Ia merupakan alat yang cocok untuk memperagakan informasi efektif, baik melalui efek optis maupun melalui gambaran visual yang berkaitan[11].

Film Animasi "Nussa dan Rara" besutan The Little Giantz Studio ini tidak hanya menyajikan tayangan yang menggemaskan, tetapi banyak mengandung nilai-nilai kebaikan yang patut untuk dicontoh oleh anak usia dini. Pada setiap episodenya menceritakan tentang kehidupan sehari-hari seorang adik kakak yang tinggal bersama umma nya. Mereka juga memiliki seorang abi, hanya saja diceritakan sedang berada diluar dan jarang ditampilkan. Alur film ini juga menceritakan seseorang yang menjalani kehidupan sehari-hari berdasarkan ajaran Islam dengan cara penyampaian karakter yang sangat mudah dipahami oleh semua orang bahkan anak usia dini sekalipun. Animasi ini memiliki pesan moral dan nilai edukasi yang tinggi. Nussa dan Rara adalah kaka beradik yang selalu saling mengingatkan dalam kebaikan. Selain itu disetiap episodenya terdapat berbagai kandungan ajaran agama Islam. Oleh karena itu, film animasi ini cocok digunakan menjadi media pembentukkan kemandirian anak usia dini. 


\section{METODE}

Penelitian ini merupakan penelitian kuantitatif dengan menggunakan metode deskriptif korelasional yang merupakan bagian dari penelitian kuantitatif yakni mendeskripsikan mengenai hubungan antara aktivitas anak pada penggunaan media film animasi "Nussa dan Rara" dengan kemandirian anak usia dini. Pendekatan kuantitatif digunakan untuk mengukur indikator-indikator variabel sehingga dapat diperoleh gambaran umum dan kesimpulan dari permasalahan yang diteliti. Pemilihan metode deskriptif korelasional didasari dengan maksud ingin mengkaji dan melihat hubungan diantara dua variabel yang akan diteliti. Sejalan dengan itu Mohammad Ali mengungkapkan bahwa studi korelasional tidak hanya dilakukan untuk memperoleh temuan-temuan terkait dengan hubungan kesejalanan antara dua atau lebih variabel, namun dapat dilakukan secara kompleks dan mendalam termasuk dasar melakukan eksplorasi yang menuntun kearah pengujian hubungan kausal. Analisis data merupakan proses mencari dan menyusun secara sistematis data yang diperoleh dari hasil wawancara, catatan lapangan, dan dokumentasi. Selanjutnya, setelah data dikumpulkan dilanjutkan dengan penganalisisan terhadap data yang diperoleh. Data yang bersifat kuantitatif yang didapatkan dari lembar observasi dianalisis menggunakan pendekatan kuantitatif korelasional. Pada data tersebut dilakukan penilaian aktivitas menonton film "Nussa dan Rara" dengan kemandirian anak usia dini.

\section{HASIL DAN PEMBAHASAN}

Berdasarkan hasil analisis yang dilaksanakan dengan pengambilan data melalui observasi kepada 9 peserta didik di RA Mubarokah Firrizqi Baregbeg Kabupaten Ciamis mengenai Aktivitas Anak pada Penggunaan Media Film Animasi "Nussa dan Rara" diperoleh rata-rata sebesar 62 yang masuk kedalam kategori cukup. Dalam kegiatan aktivitas anak pada penggunaan media film animasi "Nussa dan Rara" ini seluruh responden ikut terlibat dengan respon yang berbeda-beda. Meskipun dalam pelaksanaannya masih terdapat beberapa anak yang memerlukan bantuan, akan tetapi aktivitas ini berjalan dengan lancar dan seluruh peserta didik ikut terlibat dari awal hingga akhir. Hal ini merupakan salah satu manfaat dari penggunaan media yang dapat menarik perhatian anak. Media pembelajaran merupakan sebuah alat juga sebuah wahana, atau juga berupa perantara atau wasilah dalam rangka menyampaikan informasi berupa pengetahuan dalam sebuah proses pembelajaran di dunia pendidikan. Media pembelajaran digunakan sebagai sarana untuk belajar agar anak lebih cepat tanggap dalam menerima proses pembelajaran. Hasil penelitian Ratna tentang film "Nusa dan Rara" menyimpulkan bahwa Film Nussa dan Rara sangat dianjurkan untuk dikonsumsi oleh anak karna film ini merupakan tontonan alternati yang disesuaikan dengan anak. Film ini memiliki beberapa episode yang memuat nilai empati yang sesuai dengan perkembangan anak. Penayangan film Nussa dan Rara kepada anak dapat menamakan perilaku sosial khususnya aspek empati. setelah anak dapat mengetahui dan mengerti terhadap yang disampaikan dalam film, kemudian anak diajari untuk meresapi serta menanamkan pesan yang disampaikan didalam kehidupan sehari-hari anak sehingga di harapkan dapat berpengaruh terhadap empati anak[12]. 
Pada zamannya, media film animasi ini berkembang sangat pesat mengikuti perkembangan teknologi dan komunikasi. Dalam bidang pendidikan, media film animasi ini dapat digunakan sebagai salah satu media dalam menyampaikan pembelajaran kepada peserta didik sehingga pendidik dapat mengoptimalkan pertumbuhan dan perkembangan peserta didik. Menurut Rahayu dan Kristiyantoro yang dikutip kembali oleh Umrotul dan Lukman mengatakan bahwa pemanfataan film animasi dalam proses pembelajaran dapat meningkatkan kualitas proses dan hasil belajar, karena film animasi bersifat menarik [13]. Oleh karena itu, pemanfaatan media film animasi yang menarik ini sangat diperlukan sehingga dapat meningkatkan motivasi belajar peserta didik dan tidak membuatnya jenuh. Sejalan dengan pendapat diatas, menurut Asmani berpendapat animasi mempunyai daya tarik utama. Animasi merupakan daya tarik utama dalam mengoperasikan program multimedia interaktif. Bukan saja mampu menjelaskan suatu konsep atau proses yang sukar dijelaskan dengan media lain, animasi juga memiliki daya tarik estetika, sehingga tampilan menarik dan memotivasi pengguna untuk terlibat dalam proses pembelajaran. Media film ini juga disebut dengan media berbasis edutainment yang menggabungkan prinsip hiburan dengan pendidikan[14].

Namun, disisi lain film animasi tidak hanya memiliki keuntungan, tetap saja media ini memiliki kekurangan diantaranya adalah pada umumnya memerlukan biaya mahal dan waktu yang banyak, tidak semua peserta didik dapat mengikuti informasi yang ingin disampaikan tersebut, dan film yang tersedia tidak selalu sesuai dengan kebutuhan dan tujuan belajar yang diinginkan, kecuali film tersebut memang dirancang khusus untuk media belajar. Penelitian lain tentang film animasi memiliki pengaruh terhadap perkembangan anak usia dini. Penelitian ini dilakukan oleh Ermawati yang menyimpulkan bahwa hasil penelitian ini sesuai dengan pendapat Elisabeth Hurlock yang menjelaskan bahwa film mampu menyenangkan anak dengan membawa mereka kedunia baru manusia dan hewan, serta melakukan hal-hal yang tidak dapat dilakukannya. Digunakannya media film animasi dalam proses pembelajaran dikarenakan film animasi sangat menarik dan menyenangkan sehingga anak dengan mudah menerima pengetahuan yang diperolehnya. Sejalan juga dengan pendapat Richard dalam penjelasan karakteristik anak usia dini bahwa dongeng atau cerita merupakan kegiatan yang banyak digemari oleh anak sekaligus dapat melatih mengembangkan imajinasi dan kemampuan bahasa anak khususnya dalam hal berbicara[15].

Berdasarkan hasil penelitian, kemandirian anak usia dini di RA Mubarokah Firrizqi Baregbeg Kabupaten Ciamis menunjukkan bahwa nilai rata-rata kemandirian anak usia dini yaitu sebesar 63 yang berarti cukup. Data hasil penelitian tentang kemandirian anak usia dini di RA Mubarokah Firrizqi Baregbeg Kabupaten Ciamis diperoleh melalui teknik observasi. Berdasarkan hasil penelitian diperoleh bahwa sebagian kecil peserta didik yang kemandiriannya sudah berkembang dan sebagian besar peserta didik yang kemandiriannya belum berkembang. Hal itu terjadi dikarenakan kurangnya stimulus baik dari orang tua maupun pendidik dan penggunaan media pembelajaran yang belum optimal serta memadai. 
Kemandirian anak usia dini dapat distimulus oleh orang tua dan pendidik melalui berbagai cara. Namun, tuntutan orang tua dan pendidik terhadap kemandirian anak setidaknya tidak melebihi kemampuan yang dimiliki anak. Dengan kata lain harus mengenal dan memahami terlebih dahulu kemampuan anak dengan baik dan cermat, termasuk tahap-tahap perkembangannya. Hal itu dilakukan agar stimulus yang diberikan disesuaikan dengan kemampuan yang dimiliki oleh anak sehingga nantinya tidak ada keterpaksaan dan salah penerimaan maksud dari kata mandiri itu sendiri dan untuk menstimulasi anak pada periode absorbent mind (proses anak mencerna dan mendapatkan pengetahuan dari lingkungan sekitarnya) karena periode tersebut anak tidak akan terulang kembali. Itulah sebabnya diperlukan pendidikan anak usia dini. Kemandirian anak dapat dipengaruhi oleh pola asuh orang tua dalam memberikan stimulus perkembangan anak. Penelitian Hewi menyimpulkan bahwa pola asuh orang tua anak di suku bajo yang ada di KB Nur' Ain Mola Selatan memiliki kecenderungan untuk memanjakan anak sehingga anak belum memiliki perilaku mandiri[16].

Dalam mendidik anak untuk bisa mandiri dibutuhkan kesabaran dan pengetahuan yang cukup agar perkembangannya dapat dimaksimalkan. Dan anak usia dini bukanlah miniatur orang dewasa. Jadi, anak tidak boleh dituntut menjadi orang dewasa sebelum waktunya. Setiap anak cenderung memiliki ciri untuk mandiri karena setiap anak memiliki perasaan, pikiran, kehendak sendiri, yang semuanya merupakan totalitas psikis dan sifat-sifat yang berlainan pada tiap-tiap fase perkembangannya. Terbentuknya kemandirian dalam diri anak terkait dengan tiga aspek kemandirian yang terdiri dari aspek kognitif, aspek afektif, dan aspek psikomotor. Hal ini dapat dijelaskan melalui sebuah gambar berikut:

\section{Gambar 1. Tiga Aspek Pembentukan Kemandirian}

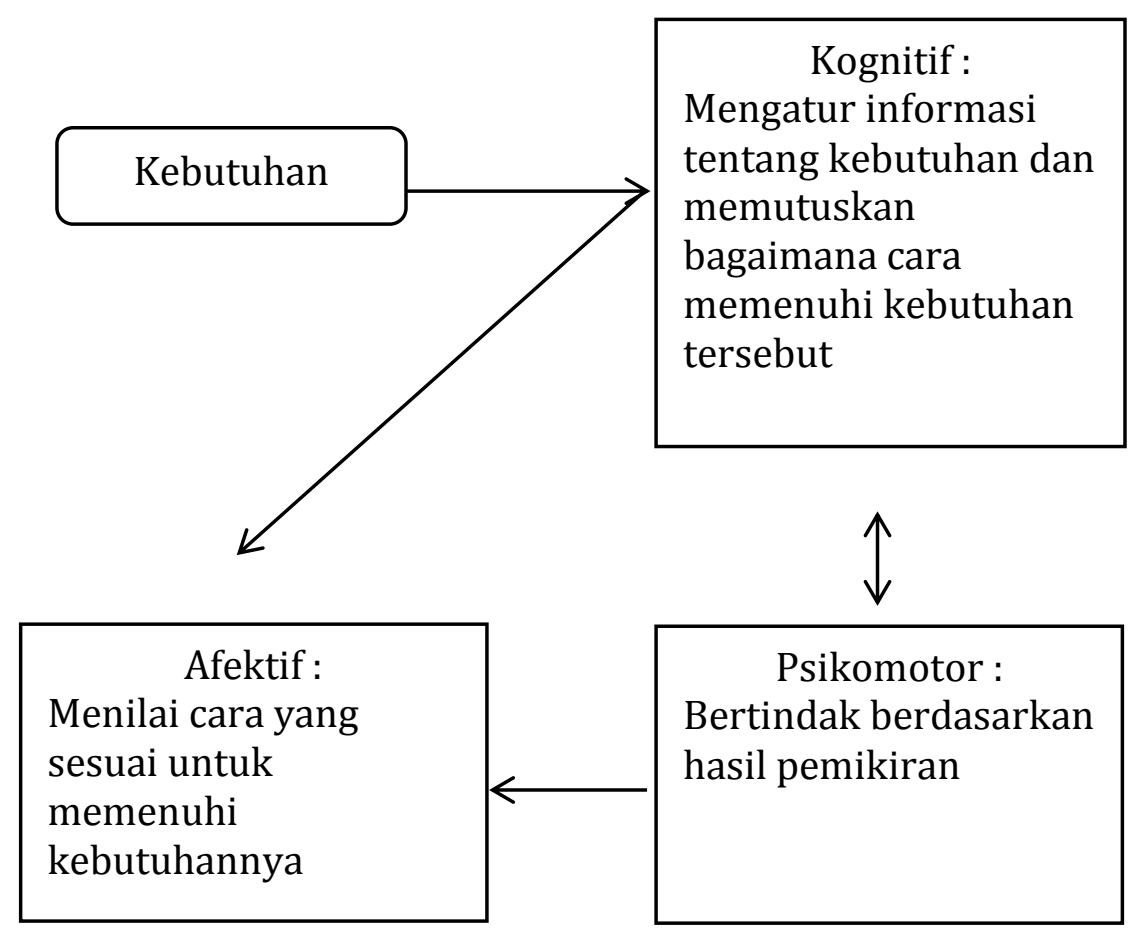


Dari penjelasan diatas, dapat disimpulkan bahwa ada tiga aspek kemandirian, yaitu yang pertama kemandirian fisik dalam konteks keterampilan hidup anak sudah mampu melakukan hal-hal sederhana dalam memenuhi kebutuhannya dengan tanpa meminta bantuan kepada orang lain seperti makan tanpa disuapi, memakai baju sendiri, memakai sepatu sendiri, dan membereskan mainan yang telah digunakan tanpa bantuan orang lain. Kedua adalah kemandirian emosional dengan cara mengorganisir perasaan dan kemauannya untuk tidak selalu bergantung kepada orang lain dan bahkan mengendalikan perasaan ketika di sekolah tidak didampingi oleh orang tuanya. Ketiga adalah kemandirian sosial ditandai dengan mampu berinteraksi dengan lingkungan sekitar dan rasa percaya diri sehingga tidak harus menunggu orang lain terlebih dahulu yang bertegur sapa. Kemandirian dan disiplin merupakan bagian yang menjadi perhatiaan oleh Montessori. Metode Montessori memberikan kebebasan dan dukungan penuh pada kemandirian anak melalui observasi dan intervensi dengan membiarkan anak memilih kegiatan sendiri dan saat anak tertarik serta konsentrasi dengan tugasnya. Dengan begitu anak akan bertanggung jawab atas pilihannya sendiri tersebut. Montessori menerapkan Metode Latihan Kehidupan Praktis pada "Children Hose" untuk melakukan kegitan sehari- hari anak dilatih kemandirian dan disiplin . Dalam kegiatan latihan kehidupan praktis, anak meniru dan mengulangi apa yang dilakukan oleh orang dewasa, dalam hal ini guru. Anak- anak meniru atau mengaplikasikan apa yang anak lihat, anak-anak juga menerapkan prinsip bahwa 'setiap bantuan berguna merupakan penghalang bagi perkembangan' jadi anak-anak akan berusaha untuk melakukannya sendiri tanpa bantuan siapapun[17].

Berdasarkan hasil perhitungan menggunakan rumus korelasi product moment diperoleh koefisien korelasi antara aktivitas anak pada penggunaan media film animasi "Nussa dan Rara" dengan kemandirian anak usia dini sebesar 0,62 angka tersebut berada pada interval 0,600 - 0,799 dengan kategori kuat. Dengan kata lain aktivitas anak penggunaan media film animasi "Nussa dan Rara" memiliki hubungan signifikansi dengan kemandirian anak usia dini di RA Mubarokah Firrizqi Baregbeg Ciamis. Selain itu, hasil perhitungan koefisien determinasi dapat disimpulkan bahwa aktivitas anak penggunaan media film animasi "Nussa dan Rara" memberi kontribusi sebesar 38,44\% terhadap kemandirian anak usia dini di RA Mubarokah Firrizqi Baregbeg Ciamis. Sedangkan 61,56\% lagi kemandirian anak usia dini di RA Mubarokah Firrizqi Baregbeg Kabupaten Ciamis ini dipengaruhi oleh faktor lain. Hasil penelitian Daviq menyimpulkan bahwa secara umum kemandirian anak usia 5-6 tahun di TK Pertiwi Provinsi Riau berada dalam kategori mulai berkembang. Secara khusus, dilihat dari masing- masing indikator, diketahui bahwa kemandirian anak usia 5-6 tahun di TK Pertiwi Provinsi Riau diperoleh hasil sebagai berikut: 1) kemampuan fisik berada pada kriteria berkembang sesuai harapan, 2) percaya diri berada pada kriteria mulai berkembang, 3) bertanggung jawab berada pada kriteria mulai berkembang, 4) disiplin berada pada kriteria mulai berkembang, 5) pandai bergaul berada pada kriteria mulai berkembang, 6) saling berbagi berada pada kriteria mulai berkembang, 7) mengendalikan emosi berada pada kriteria mulai berkembang[18]. 
Harrison dan Hummell menyatakan bahwa film animasi mampu memperkaya pengalaman dan kompetensi peserta didik pada beragam materi ajar[19]. Hegarty mengatakan bahwa dengan perkembangan teknologi, film animasi mampu menyediakan tampilan-tampilan visual yang lebih kuat dari berbagai fenomena dan informasi abstrak yang sangat berperan dalam meningkatkan kualitas hasil belajar[20]. Dan menurut Bogiages dan Hitt menambahkan peningkatan minat, pemahaman, dan keterampilan bekerja dalam kelompok pembelajaran[21].

Didalam sebuah pembelajaran peserta didik didorong agar mampu menjadi peserta didik yang mandiri. Kemandirian yang dimiliki oleh peserta didik mampu menjadikannya peserta didik yang mandiri dan secara sadar pentingnya pembelajaran tanpa adanya dorongan dari orang lain. Anak yang mandiri terdiri dari dua faktor yaitu disiplin dalam aturan dan bertindak, serta komitmen dirinya terhadap kelompok belajar. Kemandirian dapat didukung dan distimulasi oleh berbagai faktor pembelajaran salah satunya ialah penggunaan media film animasi sebuah media penyampaian materi ajar. Sehingga kemandirian anak dapat terlatih melalui pesan moral yang terdapat dalam sebuah tayangan film animasi dan mudah untuk diaplikasikan kedalam kehidupan sehari-hari.

\section{KESIMPULAN}

Penggunaan media film animasi "Nussa dan Rara" yang secara tidak langsung memiliki hubungan yang positif dengan kemandirian anak usia dini. Sehingga film animasi tersebut bisa dijadikan media pembelajaran yang efektif jika pendidik menggunakannya dengan benar. Pembentukan kemandirian anak sangat penting karena perilaku ini tidak akan mudah untuk digoyahkan pada anak usia dini yang proses penstimulusannya berjalan secara signifikan, sehingga perilaku inilah merupakan salah satu pertanda proses pertumbuhan dan perkembangan anak mengalami keberhasilan. Proses pembelajaran dengan memanfaatkan kemajuan teknologi yang digunakan oleh pendidik ini merupakan salah satu ide kreatif agar peserta didik tidak merasa bosan selama proses belajar berlangsung. Dan dibuktikan juga oleh hasil perhitungan korelasional bahwa penggunaan media film animasi "Nussa dan Rara" memiliki pengaruh yang kuat terhadap kemandirian anak usia dini.

\section{PENGHARGAAN}

Terima kasih penulis ucapkan kepada Kepala Sekolah dan Guru di RA Mubarokah Firrizqi Baregbeg Kabupaten Ciamis yang telah meluangkan waktunya untuk mengisi instrument penelitian ini dan semua pihak yang telah membantu pelaksanaan penelitian dan penulisan artikel ini. Tidak lupa ucapan terima kasih kepada editor dan reviewer Jurnal Murhum yang sudah memberikan kesempatan sehingga jurnal bisa untuk diterbitkan 


\section{REFERENSI}

[1] K. Maryani, "Penilaian dan Pelaporan Perkembangan Anak Saat Pembelajaran di Rumah di Masa Pendemi Covid-19," Murhum J. Pendidik. Anak Usia Dini, vol. 1, no. 1, pp. 41-52, 2020.

[2] S. Suriati, S. Kuraedah, E. Erdiyanti, and L. O. Anhusadar, "Meningkatkan Keterampilan Motorik Halus Anak melalui Mencetak dengan Pelepah Pisang," J. Obs. J. Pendidik. Anak Usia Dini, vol. 4, no. 1, p. 211, Nov. 2019.

[3] M. Fauziddin and M. Mufarizuddin, "Useful of Clap Hand Games for Optimalize Cogtivite Aspects in Early Childhood Education," J. Obs. J. Pendidik. Anak Usia Dini, vol. 2, no. 2, p. 162, Dec. 2018.

[4] L. Anhusadar, "Evaluasi Pelaksanaan Standar Produk Hasil Belajar pada Satuan Pendidikan Anak Usia Dini," Al-TA'DIB J. Kaji. Ilmu Kependidikan, vol. 13, no. 1, p. 34, Jun. 2020.

[5] R. Wahyuni, "Meningkatkan Kemampuan Motorik Halus Anak Melalui Finger Painting Menggunakan Tepung Singkong," Murhum J. Pendidik. Anak Usia Dini, vol. 1, no. 1, pp. 28-40, 2020.

[6] S. S. Ndari, "Metode Perkembangan Sosial Emosi Anak usia Dini." Jawa Barat: Edu Publisher. Edu Publisher, 2018.

[7] I. Islamiyah, F. B. Awad, and L. Anhusadar, "Outcome Program Bina Keluarga Balita (Bkb): Konseling Orang Tua Dalam Tumbuh Kembang Anak Usia Dini," Zawiyah J. Pemikir. Islam, vol. 6, no. 1, p. 38, Jul. 2020.

[8] M. P. Ahmad Susanto, Bimbingan dan Konseling di Sekolah: Konsep, Teori, dan Aplikasinya. Kencana, 2018.

[9] S. Pangestu, S. Saparahayuningsih, and D. Delrefi, "Kemandirian Anak Dalam Pembelajaran Pengembangan Sosial Emosional (Studi Deskriptif Kuantitatif di PAUD Assalam Muara Bangkahulu Kota Bengkulu)," J. Ilm. Potensia, vol. 2, no. 2, pp. 86-90, 2017.

[10] E. N. Affrida, "Strategi Ibu dengan Peran Ganda dalam Membentuk Kemandirian Anak Usia Pra Sekolah,” J. Obs. J. Pendidik. Anak Usia Dini, vol. 1, no. 2, p. 114, Dec. 2017.

[11] A. Wulandari, "Penggunaan Media Film Animasi Untuk Meningkatkan Kemampuan Berbicara Anak Autis Kelas III SD DI SLB Rela Bhakti I Gamping," WIDIA ORTODIDAKTIKA, vol. 5, no. 6, pp. 560-571, 2016.

[12] Y. Ade Ratna Sari Hutasuhut, "Analisis Pengaruh Film Nussa dan Rara terhadap Empati Anak Usia Dini di Kota Padang," Jurnall Pendidik. Tambusai, vol. 4, no. 2, pp. 1237-1246, 2020.

[13] U. Hasanah and L. Nulhakim, "Pengembangan Media Pembelajaran Film Animasi Sebagai Media Pembelajaran Konsep Fotosintesis," J. Penelit. dan Pembelajaran $I P A$, vol. 1, no. 1, p. 91, Nov. 2015.

[14] A. Arsyad, "Media pembelajaran.” Jakarta: PT Raja grafindo persada, 2011.

[15] N. Ermawati and S. Mahmudah, "Pengaruh Film Animasi Terhadap Perkembangan Berbicara Anak." 2009.

[16] L. Hewi, P. U. N. Jakarta, J. R. Jl, and J. T. Muka, "Kemandirian Usia Dini di Suku Bajo (Studi Kasus pada Anak Usia 4-6 Tahun di KB Nur' Ain Mola Selatan Kabupaten Wakatobi Provinsi Sulawesi Tenggara tahun 2015)," JPUD - J. Pendidik. Usia Dini UNJ, no. 2, 2015.

[17] Nasution Armayanti Raisah, "Penanamana Disiplin dan Kemandirian Anak Usia Dini dalam Metode Maria Montessori," Progr. Stud. Pendidik. Guru Raudhatul Athfal, vol. 05, no. 02, p. 11, 2017. 
[18] Daviq Chairilsyah, "Analisis Kemandirian Anak Usia Dini," PAUD Lect. J. Pendidik. Anak Usia Dini, vol. 3, no. 01, pp. 88-98, Oct. 2019.

[19] M. Rahmatullah, "Pengaruh pemanfaatan media pembelajaran film animasi terhadap hasil belajar," J. Penelit. Pendidik, vol. 12, no. 1, pp. 178-186, 2011.

[20] M. M. Fatahullah, "Pengaruh media pembelajaran dan kemampuan berpikir kritis terhadap hasil belajar IPS," J. Pendidik. Dasar UNJ, vol. 7, no. 2, pp. 237-252, 2016.

[21] E. Purwanto, W. Sunarno, and N. S. Aminah, "Pembelajaran Fisika dengan Contextual Teaching And Learning Menggunakan Media Animasi Flash dan Video Ditinjau dari Kemampuan Berpikir Abstrak dan Kemampuan Verbal Siswa," INKUIRI J. Pendidik. IPA, vol. 4, no. 4, pp. 77-86, 2015. 